\title{
In Situ Analysis of the Liquid Phase Sintering Process of $\alpha$-SiC Ceramics
}

\author{
LIANG Han-Qin, YAO Xiu-Min, HUANG Zheng-Ren, ZENG Yu-Ping
}

(The State Key Lab of High Performance Ceramics and Superfine Microstructure, Shanghai Institute of Ceramics, Chinese Academy of Sciences, Shanghai 200050, China)

\begin{abstract}
The densification process of liquid phase sintered $\mathrm{SiC}$ ceramics with $\mathrm{Al}_{2} \mathrm{O}_{3}$ and $\mathrm{Y}_{2} \mathrm{O}_{3}$ as sintering additives was investigated by in situ measurement apparatus combined with conventional methods. The shrinkage curve, morphology of the sample and liquid phase formation process simulation were observed by high temperature in-situ observation furnace. The relative density, flexural strength and microstructure evolution were characterized by analysis of samples sintered at temperatures ranging from $1640^{\circ} \mathrm{C}$ to $1920^{\circ} \mathrm{C}$ at $40^{\circ} \mathrm{C}$ interval. The obvious temperature that liquid phase began to function was confirmed between $1640^{\circ} \mathrm{C}$ to $1680^{\circ} \mathrm{C}$. The classical liquid phase sintering theory was testified. Highly-densified SiC ceramics were obtained by being sintered at $1880^{\circ} \mathrm{C}$, of which the relative density was $(99.46 \pm 0.37) \%$, and the flexural strength was $(650 \pm 26) \mathrm{MPa}$.
\end{abstract}

Key words: SiC; liquid phase sintering; in-situ measurement; microstructure

Silicon carbide ceramics possess high performances such as high strength, high hardness, high thermal conductivity, low thermal expansion coefficient and so on, which make silicon carbide ceramics attractive materials for the industry sectors ${ }^{[1-4]}$. However, it is difficult to obtain highly-densified silicon carbide ceramics due to the high covalency nature of $\mathrm{Si}-\mathrm{C}$ bond ${ }^{[5-6]}$. In order to achieve the densification of $\mathrm{SiC}$ ceramics, many sintering methods have been invented such as hot pressing sintering, reaction bonded sintering, gas pressure sintering and pressureless sintering ${ }^{[7-10]}$. According to the state of the sintering additives taking effect during the sintering process, the pressureless sintering methods can be divided into pressureless solid state sintering and pressureless liquid phase sintering. By comparison, high-performance $\mathrm{SiC}$ ceramics can be fabricated at relatively low temperature by pressureless liquid phase sintering. As a result, pressureless liquid phase sintering has enormous potentiality to be widely used in industry. Though the pressureless liquid phase sintering method has great advantage, it encounters huge obstacles as well. For example, partially sintered and deformed samples are usually obtained when fabricating complex and big scale samples. In order to solve this problem, it is necessary to investigate the liquid phase sintering process deeply.

Nowadays, many in situ measurement apparatus have emerged and played a big role in the materials researching. For example, furnace equipped with CCD camera can re- cord the sintering information including morphology, shrinkage, wettability of the samples during the sintering process $^{[11-12]}$. In situ XRD can analyze the phase composition changes during the heating process ${ }^{[13-14]}$. These all contribute to deepening our knowledge of the sintering process and the sintering mechanisms.

So in this study, we adopt these in-situ measurement apparatus to investigate deeply into the liquid phase sintering process, which would provide useful information for us to adjust the sintering parameters of liquid phase sintering and improve the performance of liquid phase sintered $\mathrm{SiC}$ ceramics. However, due to the particularity of liquid phase sintering, which needs powder bed to inhibit the liquid phase volatilization during the sintering process, the use of in-situ apparatus will be restricted ${ }^{[15-16]}$. So combination of the in-situ measurement with some conventional research methods should be a good solution, i.e. investigating the microstructure, relative density and phase composition of the sample at each designed temperature in the condition that in-situ apparatus are restricted.

Among various sintering additives, the $\mathrm{Al}_{2} \mathrm{O}_{3}-\mathrm{Y}_{2} \mathrm{O}_{3}$ system are the most popular sintering additives for the liquid phase sintering of $\mathrm{SiC}$ ceramics because of their good effect and low cost ${ }^{[17-19]}$. So we also employ $\mathrm{Al}_{2} \mathrm{O}_{3}$ and $\mathrm{Y}_{2} \mathrm{O}_{3}$ as the sintering additives. The liquid phase formation process was simulated, the shrinkage and morphology changes during the sintering process was observed. The phase composition changes during the heating 
process was also studied.

\section{Experimental procedure}

\subsection{Materials preparation}

Commercially available $\alpha-\mathrm{SiC}(0.5 \mu \mathrm{m}$; FCP $15 \mathrm{C}$, SIKA TECH., Lillesand, Norway), $\mathrm{SiO}_{2}(0.5 \mu \mathrm{m}$; Sinopharm Group Co., Ltd., China), $\mathrm{Al}_{2} \mathrm{O}_{3}(0.4 \mu \mathrm{m}$; Fenghe Ceramic Co., Ltd., China) and $\mathrm{Y}_{2} \mathrm{O}_{3}(4 \mu \mathrm{m}$; Yuelong Chemical Co., Ltd., China) were used as the starting powders in the present work.

For the preparation of $\mathrm{SiC}$ green bodies, 94wt $\% \mathrm{SiC}$, $3.64 w t \% \mathrm{Al}_{2} \mathrm{O}_{3}$ and $2.36 \mathrm{wt} \% \mathrm{Y}_{2} \mathrm{O}_{3}$ were mixed. The mixture was ball-milled in ethanol for $4 \mathrm{~h}$ with silicon carbide media in a planetary mill at $300 \mathrm{r} / \mathrm{min}$. After milling, the resulting slurries were dried in vacuum evaporator at $60^{\circ} \mathrm{C}$ for $24 \mathrm{~h}$. Then the powders were sieved through a 100 mesh screen to avoid agglomeration. The as-received powders were compacted by cold uniaxial pressing at a pressure of $20 \mathrm{MPa}$ and followed by cold isostatic pressing at $200 \mathrm{MPa}$. Before sintering, all the green bodies were slowly heated to $1000^{\circ} \mathrm{C}$ with dwell time of $1 \mathrm{~h}$ to remove the binder. In order to study the microstructure evolution during the sintering process, sintering of the green samples was performed in a closed graphite crucible containing coarse $\mathrm{Al}_{2} \mathrm{O}_{3}, \mathrm{Y}_{2} \mathrm{O}_{3}$ and $\mathrm{SiC}$ powders as powder beds. The samples were heated to $1600^{\circ} \mathrm{C}$ at a heating rate of $10^{\circ} \mathrm{C} / \mathrm{min}$, followed by being heated at $2{ }^{\circ} \mathrm{C} / \mathrm{min}$ up to the predetermined temperatures between $1640^{\circ} \mathrm{C}$ and $1920^{\circ} \mathrm{C}$ at $40^{\circ} \mathrm{C}$ intervals, at which they were kept for $1 \mathrm{~h}$.

\subsection{Materials Characterization}

Cylindrical $\mathrm{SiC}$ green body with the dimension of $\Phi 15.0 \mathrm{~mm} \times 10 \mathrm{~mm}$ was placed in a real-time observation furnace (Thermo-Optical-Measurement System (TOMS), Fraunhofer Institute for Silicate Research, Germany) to observe its shrinkage behavior. The sample was heated to $1600^{\circ} \mathrm{C}$ at a heating rate of $10{ }^{\circ} \mathrm{C} / \mathrm{min}$, followed by being heated at $2{ }^{\circ} \mathrm{C} / \mathrm{min}$ up to $1920^{\circ} \mathrm{C}$.

The as-sintered samples were machined into rectangular bars with a dimension of $4 \mathrm{~mm} \times 3 \mathrm{~mm} \times 36 \mathrm{~mm}$ and the surfaces of the bars were polished using polishing machinery with diamond slurries. In order to minimize the stress concentration induced during the machining process, the edges of all the bars were chamfered.

The bulk densities of the samples were measured by Archimedes method using distilled water as immersing medium. The flexural strength of the samples was measured in air using an Instron universal testing machine (Model 5566) with a span of $30 \mathrm{~mm}$ and a cross-head speed of $0.5 \mathrm{~mm} / \mathrm{min}$.
The phase identification of the composites was carried out by X-ray diffraction (XRD, D8 ADVANCE, Bruker, Germany). The diffraction data were collected within $10^{\circ}-80^{\circ} 2 \theta$ range and a scanning step of $10^{\circ} / \mathrm{min}$ were used. The fracture surfaces and the chemical composition of the samples were investigated by scanning electron microscopy (SEM, Magellan 400, FEI, USA) with an energy dispersive spectrometer.

\section{Results and Discussion}

Figure 1 shows the shrinkage curve and images of the sample during the sintering process obtained from the measurement of TOMAC. Generally speaking, the sample exhibited innate thermal expansion behavior before $1580^{\circ} \mathrm{C}$ and began to shrink around $1580^{\circ} \mathrm{C}$. But an abnormal shrinkage took place during the expansion period, to be specific, the sample began to shrink from about $1250^{\circ} \mathrm{C}$ to $1450^{\circ} \mathrm{C}$, and then continued to expand until $1580^{\circ} \mathrm{C}$. According to Kinsman's study ${ }^{[20]}$, the solid state reaction between $\mathrm{Y}_{2} \mathrm{O}_{3}$ and $\mathrm{Al}_{2} \mathrm{O}_{3}$ would take place at about this temperature range, which accounted for the shrinkage. In addition, there was two phenomena worthy to note during the whole in-situ observation process.

Firstly, the total shrinkage rate was about $8 \%$, which was far below the necessary shrinkage rate $(\sim 18 \%)$ for a highly densified sample. As was known to us, high densification of liquid phase sintered $\mathrm{SiC}$ ceramics should be fabricated with powder bed, which was essential to inhibit the liquid phase volatilization and ensure the liquid phase take full effect during the sintering process. Without powder bed, liquid phase volatilization would happen during the sintering process. Evidence can be clearly found from the in-situ images obtained during the sintering process, as shown in Fig. 1(b), obvious shade can be seen in the

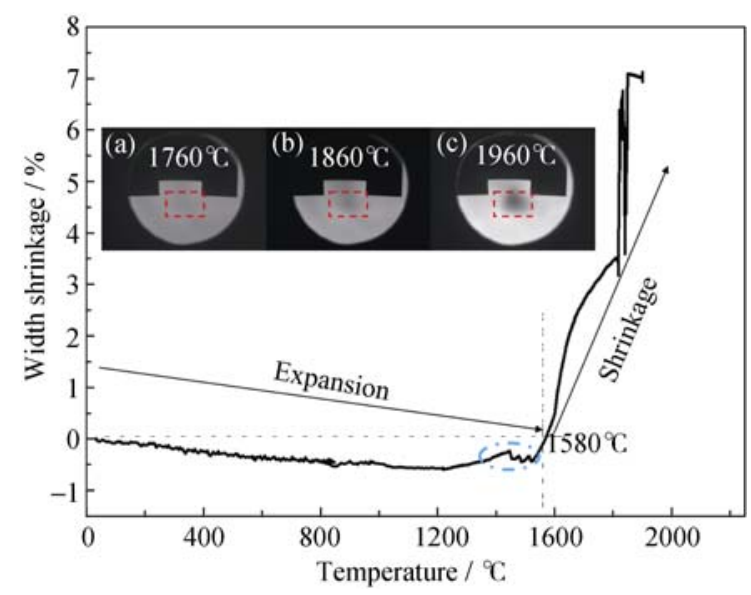

Fig. 1 Shrinkage curve and in situ images at (a) $1760^{\circ} \mathrm{C}$, (b) $1860^{\circ} \mathrm{C}$ and (c) $1960^{\circ} \mathrm{C}$ of the $\mathrm{SiC}$ green bodies obtained by TOMAC system 
images, which indicated that many volatilized species had deposited on the observation window and disturbed the imaging. The volatilization became more serious when the sintering temperature rose to $1960^{\circ} \mathrm{C}$, resulting in large amount of volatilized species depositing on the observation window. Secondly, the shrinkage began at $1580^{\circ} \mathrm{C}$, which was consistent with that of the result reported by Zhang ${ }^{[21]}$. It maybe means that the liquid phase sintering process would approximate to the solid phase sintering process in such a condition.

As reported in our previous work, powder bed plays an important role in the densification process of liquid phase sintered SiC ceramics. However, covered by the powder bed, it is unable to measure the shrinkage and observe the morphology in situ. In order to get the information of the densification process, we adopt the 'division' method to investigate the sintering process. Specifically speaking, we separately sintered the samples at each predetermined temperature range from $1640^{\circ} \mathrm{C}$ to $1920^{\circ} \mathrm{C}$ at $40^{\circ} \mathrm{C}$ interval. At first, the relative density of the samples sintered at each predetermined temperature were measured, as shown in Fig. 2. The relative density of the samples sintered at $1640^{\circ} \mathrm{C}$ was $58 \%$, a little higher than that of the green body, which indicated that the densification of the samples just began. When the temperature was elevated to $1760^{\circ} \mathrm{C}$, the relative density of the sample increased rapidly to $97 \%$, which indicated that the densification almost accomplished at this temperature. Above $1760^{\circ} \mathrm{C}$, the relative density slightly increased with the elevating of the sintering temperatures. In the present experiment, the maximum relative density was $99.46 \%$ for the sample sintered at $1880^{\circ} \mathrm{C}$. When the sintering temperature was further elevated to $1920^{\circ} \mathrm{C}$, the relative density slightly decreased.

The flexural strength of the prepared samples were also plotted as a function of the sintering temperatures in Fig. 2. The flexural strength of the sample sintered at $1640^{\circ} \mathrm{C}$ was only $35 \mathrm{MPa}$, slightly higher than that of the green body. When the sintering temperature increased from $1720^{\circ} \mathrm{C}$ to $1760^{\circ} \mathrm{C}$, the strength of the samples increased rapidly from $282 \mathrm{MPa}$ to $513 \mathrm{MPa}$, which agreed with the variation trend of relative density. Both of them testified that the densification critical temperature range was from the temperature $1720^{\circ} \mathrm{C}$ to $1760^{\circ} \mathrm{C}$. The sintering process should be controlled to obtain high-performance ceramics. When the sintering temperature further increased, the strength gradually increased and reached the maximum value of $650 \mathrm{MPa}$ at $1880^{\circ} \mathrm{C}$.

Though nowadays in-situ XRD plays an important part in the analyzing of the phase composition change with temperature, it encounters problems when it is applied to investigate the phase composition evolution of liquid phase sintered $\mathrm{SiC}$ ceramics. Without powder bed, the phase composition would be different from that with powder bed. But the in-situ phase composition analysis would not be conducted with the existence of powder bed.

But it is indispensable to examine the possible phase composition change during the sintering process in order to get deep understanding of the liquid phase sintering process of SiC ceramics. So XRD analysis of the samples sintered at each predetermined sintering temperature were conducted, as shown in Fig. 3. It can be seen that the secondary phases in the samples were all YAG phase from $1640^{\circ} \mathrm{C}$ to $1920^{\circ} \mathrm{C}$, which benefited from the powder bed used during the whole sintering process. In addition, as the temperature increased, the XRD peak intensities of YAG crystals became larger. At the same time, the peak width of the $\mathrm{SiC}$ crystals became narrow with the increasing of sintering temperature, which indicated that the $\mathrm{SiC}$ crystal grew together with the amount of YAG crystal increasing.

Microstructure analysis is very important in the investigation of sintering process. But these in-situ phenomena happen inside of the samples, which are difficult to be

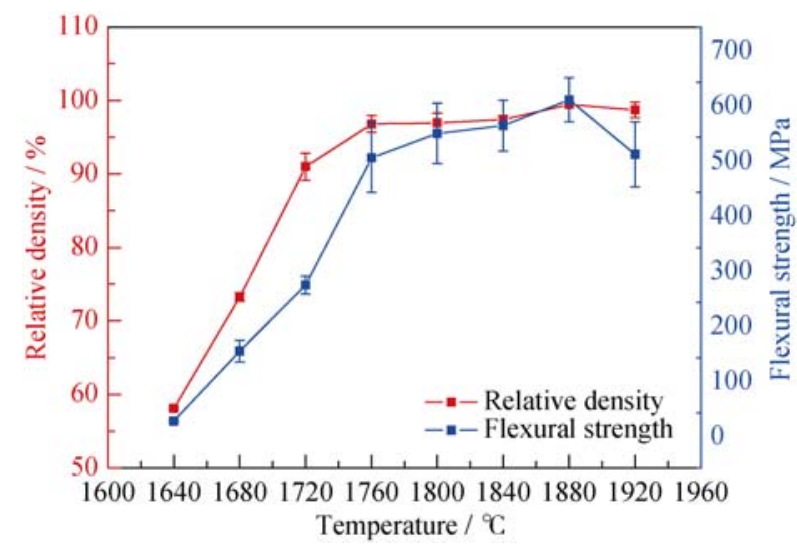

Fig. 2 Evolution of relative density and flexural strength as function of sintering temperatures

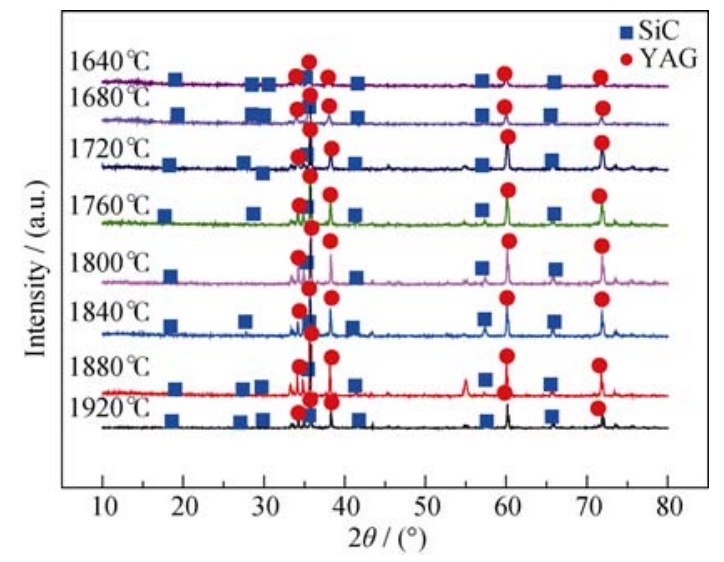

Fig. $3 \mathrm{XRD}$ analysis of samples heated at temperature from $1640^{\circ} \mathrm{C}$ to $1920^{\circ} \mathrm{C}$ 
observed in situ. An alternative method is to analysis the microstructure of the sample sintered at each designed temperature, which preserves the approximately in-situ information during the cooling process. And these phenomenon can be observed from the SEM images of the fracture surfaces of the samples, as shown in Fig 4. In addition to some particles agglomeration by the initial stage sintering, no large difference from that of the green sample was found in the sample sintered at $1640^{\circ} \mathrm{C}$ (seen from Fig. 4(a)). When the sintering temperature reached at $1680^{\circ} \mathrm{C}$, the liquid phase was clearly observed to wet and cover the SiC particles (seen from Fig. 4(b)), which indicated the sintering temperature that liquid phase obviously began to function was not so high as the eutectic temperature of $\mathrm{Al}_{2} \mathrm{O}_{3}-\mathrm{Y}_{2} \mathrm{O}_{3}$ system $\left(1760^{\circ} \mathrm{C}\right)$ and not that low as the eutectic temperature of the $\mathrm{SiO}_{2}-\mathrm{Al}_{2} \mathrm{O}_{3}-\mathrm{Y}_{2} \mathrm{O}_{3}$ system (about $1400^{\circ} \mathrm{C}$ ), but a median temperature. Two reasons may accounted for the liquid phase functioning temperature: (1) the amount of liquid phase became enough until $1680^{\circ} \mathrm{C}$; (2) the viscosity of liquid phase decreased to make quick flow until $1680^{\circ} \mathrm{C}$. As the sintering temperature increased, the amount of liquid phase increased, which filled pores and rearranged $\mathrm{SiC}$ particles ${ }^{[22]}$. The pores in the sample began to decrease and the samples became more densified. According to the microstructure and properties of the samples, the sintering process of LPS $\mathrm{SiC}$ can be divided into three stages. The first stage was the sintering process at $1680^{\circ} \mathrm{C}-1720^{\circ} \mathrm{C}$. In this stage, a large amount of liquid phase formed and gave rise to the particles' rearrangement, which was crucial to the liquid phase sintering. After that, during the temperature range $1720^{\circ} \mathrm{C}$ to $1800^{\circ} \mathrm{C}, \mathrm{SiC}$ particles underwent a process named solution and reprecipitation ${ }^{[23]}$.

At this stage, smaller grains dissolved in the liquid phase and reprecipitated at the surface of larger $\mathrm{SiC}$ grains $^{[24]}$. As a result, the grains densified at a high shrinkage rate, which was in agreement with Fig. 4(d) and (e). It was clear to see that the samples became more compacted accompanying with further filling of pores and growth of grains. However, Fig. 4(f) and (g) revealed that the samples had a similar microstructure at $1840^{\circ} \mathrm{C}$ and $1880^{\circ} \mathrm{C}$. This may be good evidence that they were both at the last stage of liquid phase sintering, which included solid-state diffusion and coarsening of grains. However, a larger grain size results in a longer diffusion distance hence a reduced rate of densification ${ }^{[23]}$. And the rigid solid skeleton formed in this stage also prohibited densification. Therefore, the pores can be eliminated until $1880^{\circ} \mathrm{C}$ and a uniform and dense microstructure can be obtained. But when the sample was heated above $1880^{\circ} \mathrm{C}$, the pores were observed again and the cohesion between the
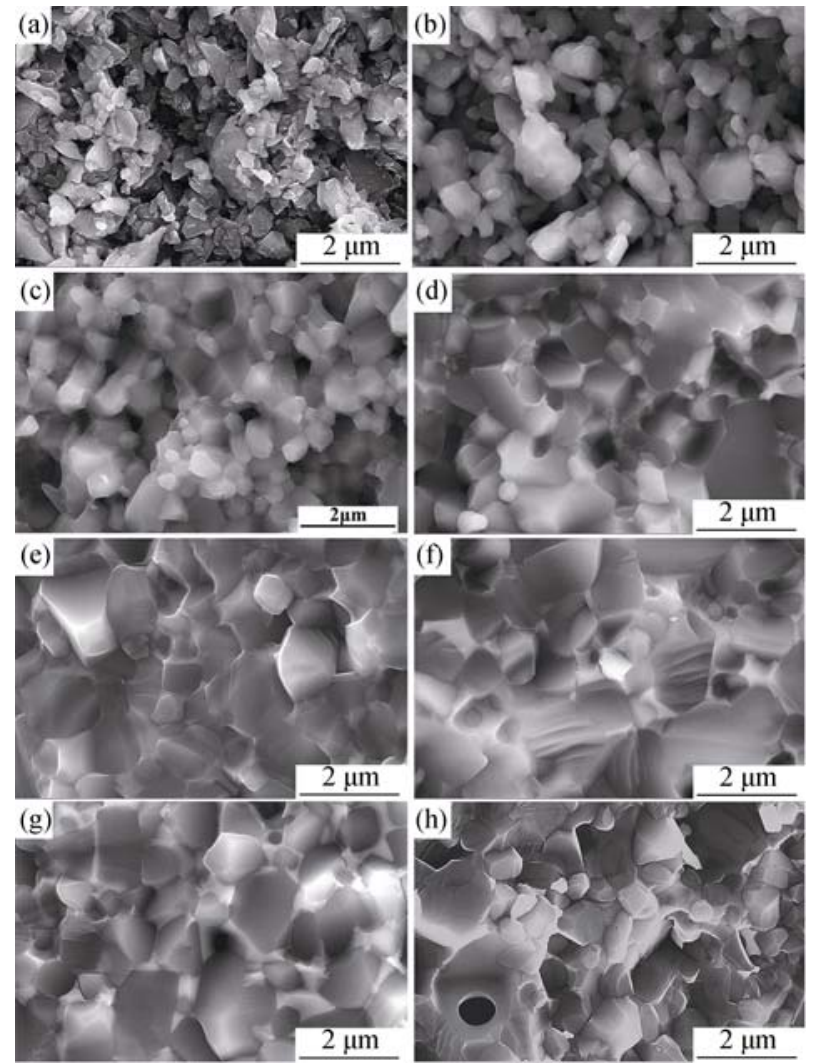

Fig. 4 SEM fracture surface micrographs of samples sintered at different temperatures

(a) $1640^{\circ} \mathrm{C}$; (b) $1680^{\circ} \mathrm{C}$; (c) $1720^{\circ} \mathrm{C}$; (d) $1760^{\circ} \mathrm{C}$; (e) $1800^{\circ} \mathrm{C}$; (f) $1840^{\circ} \mathrm{C}$; (g) $1880^{\circ} \mathrm{C}$; (h) $1920^{\circ} \mathrm{C}$

particles became loose, shown in Fig. 4(h). The liquid phase seemed to disappear from the boundaries of $\mathrm{SiC}$ grains. Therefore, the optimal sintering temperature was determined to be $1880^{\circ} \mathrm{C}$, which was consistent with the result from the relative density and the flexural strength.

The liquid phase formation process is important to analysis the liquid phase sintering process of $\mathrm{SiC}$ ceramics. However, above-mentioned methods all failed to characterize the liquid phase formation process. In order to get further understanding of the behavior of the liquid phase, the liquid phase formation process was simulated. It almost reaches a consensus that the sintering additives $\mathrm{Al}_{2} \mathrm{O}_{3}$ and $\mathrm{Y}_{2} \mathrm{O}_{3}$ would form eutectic liquid phase with the $\mathrm{SiO}_{2}$ on the surface of $\mathrm{SiC}$ particles. $\mathrm{So}_{\mathrm{SiO}_{2}}, \mathrm{Al}_{2} \mathrm{O}_{3}$ and $\mathrm{Y}_{2} \mathrm{O}_{3}$ powders were homogeneously mixed, followed by being pressed into cylindrical sample and then heated in the realtime observation furnace on a mirror-polished $\mathrm{SiC}$ plate. The content of $\mathrm{SiO}_{2}$ on $\mathrm{SiC}$ was calculated according to the oxygen content analysis of the $\mathrm{SiC}$ powder (about $0.98 \mathrm{wt} \%)$. Fig. 5 shows the melting and wetting process of the cylindrical sample on $\mathrm{SiC}$ plate. Though the sample began to shrink at about $1250^{\circ} \mathrm{C}$ according to Fig. 1, no change of the morphology was found until $1450^{\circ} \mathrm{C}$. The insufficient contact of $\mathrm{Al}_{2} \mathrm{O}_{3}-\mathrm{Y}_{2} \mathrm{O}_{3}$ with $\mathrm{SiO}_{2}$ in the 


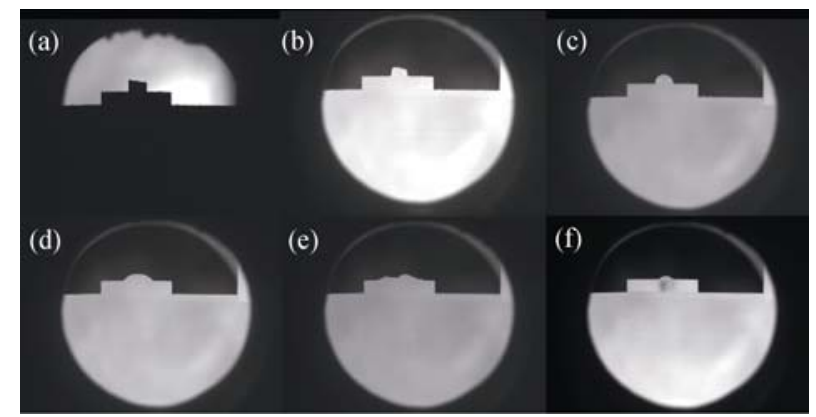

Fig. 5 "Simulation" of the liquid phase composition melting and wetting process on the $\mathrm{SiC}$ wafer. Morphologies of six characteristic temperature points

(a) $35^{\circ} \mathrm{C}$; (b) $1450^{\circ} \mathrm{C}$; (c) $1481^{\circ} \mathrm{C}$; (d) $1582^{\circ} \mathrm{C}$; (e) $1644^{\circ} \mathrm{C}$; (f) $1793^{\circ} \mathrm{C}$

actual $\mathrm{SiC}-\mathrm{Al}_{2} \mathrm{O}_{3}-\mathrm{Y}_{2} \mathrm{O}_{3}$ sintering process may account for the difference. Though some difference, the "simulation process" gave out some hints of the real sintering process as well. In the condition of close contact of $\mathrm{Al}_{2} \mathrm{O}_{3}-\mathrm{Y}_{2} \mathrm{O}_{3}$ with $\mathrm{SiO}_{2}$, the cylindrical sample transformed into meniscus at $1481^{\circ} \mathrm{C}$, slightly spread at $1582^{\circ} \mathrm{C}$, completely spread at $1644^{\circ} \mathrm{C}$, and vastly evaporated at $1793^{\circ} \mathrm{C}$, respectively, as shown in Fig. 5. However, during the real sintering process, the contact of $\mathrm{Al}_{2} \mathrm{O}_{3}-\mathrm{Y}_{2} \mathrm{O}_{3}$ with $\mathrm{SiO}_{2}$ was not that close, the liquid phase transformation temperature would be delayed correspondingly. The delay of the transformation temperature has been testified by the above mentioned microstructure analysis.

\section{Conclusion}

The liquid phase sintering process of $\mathrm{SiC}$ ceramics can be characterized by in-situ apparatus including the in-situ observation furnace, in-situ XRD and so on. Information such as the shrinkage process, morphology change and phase composition change can be obtained. The real shrinkage was found to happen at $1580^{\circ} \mathrm{C}$. The liquid phase volatilization was also observed during the sintering process. YAG was found to be the secondary phase from $1640^{\circ} \mathrm{C}$ to $1920^{\circ} \mathrm{C}$, which was beneficial from the powder bed. Through the analysis of the relative density and microstructure, the three stages of liquid phase sintering was divided. The optimal sintering temperature was found to be $1880^{\circ} \mathrm{C}$ and the highest flexural strength was $(650 \pm$ 26) $\mathrm{MPa}$.

\section{References:}

[1] MULLA M, KRSTIC V. Pressureless sintering of $\beta$-SiC with $\mathrm{Al}_{2} \mathrm{O}_{3}$ additions. J. Mater. Sci., 1994, 29: 934-938.

[2] VOLE E, ROOSEN A, HARTUNG W, et al. Electrical and thermal conductivity of liquid phase sintered SiC. J. Eur. Ceram. Soc., 2001, 21: 2089-2093.

[3] LEE S H. Low temperature pressureless sintering of SiC using an aluminum borocarbide additive. J. Am. Ceram. Soc., 2011, 94: 2746-2748.

[4] ZHANG J X, JIANG D L, LIN Q L, et al. Gelcasting and pressureless sintering of silicon carbide ceramics using $\mathrm{Al}_{2} \mathrm{O}_{3}-\mathrm{Y}_{2} \mathrm{O}_{3}$ as the sintering additives. J. Eur. Ceram. Soc., 2013, 33: 1695-1699.

[5] LEE S G, SHIM W H, KIM J Y, et al. Effect of sintering additive composition on fracture toughness of liquid phase sintered $\mathrm{SiC}$ ceramics. J. Mater. Sci. Lett., 2001, 20: 143-146.

[6] CIUDAD E, BORRERO L O, RODRIGUEZ R F, et al. Effect of intergranular phase chemistry on the sliding-wear resistance of pressureless liquid phase sintered alpha-SiC. J. Eur. Ceram. Soc., 2012, 32: 511-516.

[7] CHAKRABARTI O, DAS P, MUKERJI J. Growth of SiC particles in reaction sintered SiC. Mater. Chem. Phys., 2001, 67: 199-202.

[8] DIJEN V, MAYER E. Liquid phase sintering of silicon carbide. $J$. Eur. Ceram. Soc., 1996, 16: 413-420.

[9] KIMYW, MITOMO M, HIROTSURU H. Grain growth and fracture toughness of fine grained silicon carbide ceramics. J. Am. Ceram. Soc., 1995, 78: 3145-3148.

[10] YAND X, LIU X J, HUANG Z R, et al. Vickers indentation crack analysis of solid-state-phase-sintered silicon carbide ceramics. $\mathrm{Ce}$ ram. Int., 2013, 39: 841-845.

[11] MOTTA F V, BALESTRA R M, RIBEIRO S, et al. Wetting behaviour of $\mathrm{SiC}$ ceramics. Part I. $\mathrm{E}_{2} \mathrm{O}_{3} / \mathrm{Al}_{2} \mathrm{O}_{3}$. Mater. Lett., 2004, 58: 2805-2809.

[12] TAGUCHI S P, MOTTA F V, BALESTRA R M, et al. Wetting behavior of $\mathrm{SiC}$ ceramics. Part II. $\mathrm{Y}_{2} \mathrm{O}_{3} / \mathrm{Al}_{2} \mathrm{O}_{3}$ and $\mathrm{Sm}_{2} \mathrm{O}_{3} / \mathrm{Al}_{2} \mathrm{O}_{3}$. Mater. Lett., 2004, 58: 2810-2814.

[13] VALENTINI L, DALCONI M C, FAVERO M, et al. In-situ xrd measurement and quantitative analysis of hydrating cement: implications for sulfate incorporation in C-S-H. J. Am. Ceram. Soc., 2015, 98(4): 1259-1264.

[14] LANGE M, KOBALZ M, BERGMANN J, et al. Structural flexibility of a copper-based metal-organic framework: sorption of C-4-hydrocarbons and in situ XRD. J. Mater. Chem. A, 2014, 2(21): $8075-8085$.

[15] WINN E J, CLEGG W J. Role of the powder bed in the densification of silicon carbide sintered with yttria and alumina additives. $J$. Am. Ceram. Soc., 1999, 82: 3466-3470.

[16] LIANG H Q, YAO X M, LIU X J, et al. The effect of powder bed on the liquid phase sintering of a-SiC. Mater. \& Des., 2014, 56: 1009-1013. 
[17] HUANG R, GU H, ZHANG J X, et al. Effect of $\mathrm{Y}_{2} \mathrm{O}_{3}-\mathrm{Al}_{2} \mathrm{O}_{3}$ ratio on inter-granular phases and films in tape-casting alpha-SiC with high toughness. Acta. Mater., 2005, 53: 2521-2529.

[18] RODRIGUEZ F R, ORTIZ A L, LOPEZ O B, et al. Effect of the sintering additive content on the non-protective oxidation behaviour of pressureless liquid-phase-sintered alpha-SiC in air. J. Eur. Ceram. Soc., 2010, 30: 1513-1518.

[19] ORTIZ A L, LOPEZ O B, QUADIR M Z, et al. A route for the pressureless liquid-phase sintering of $\mathrm{SiC}$ with low additive content for improved sliding-wear resistance. J. Eur. Ceram. Soc., 2012, 32: 965-973.

[20] KINSMAN K M, MCKITTRICK J, SLUZKY E, et al. Phase development and luminescence in chromium - doped yttrium alumi- num garnet (YAG: Cr) phosphors. J. Am. Ceram. Soc., 1994, 77: 2866-2872.

[21] ZHANG J X, JIANG D L, LIN Q L, et al. Preparation of silicon carbide ceramics by aqueous gelcasting and pressureless sintering. J. Chn. Ceram. Soc., 2012, 8: 1154-1157.

[22] ORTIZ A L, BORRERO L O, QUADIR M Z, et al. A route for the pressureless liquid phase sintering of $\mathrm{SiC}$ with low additive content for improved sliding-wear resistance. J. Eur. Ceram. Soc., 2012, 32: 965-973.

[23] GERMAN R, SURI P, PARK S. Review: liquid phase sintering. $J$. Mater. Sci., 2009, 44: 1-39.

[24] YE H, PUJAR V V, PADTURE N P. Coarsening in liquid phase sintered alpha-SiC. Acta. Mater., 1999, 47: 481-487.

\title{
液相烧结碳化硅陶瓷的原位研究
}

\author{
梁汉琴，姚秀敏，黄政仁，曾宇平 \\ (中国科学院 上海硅酸盐研究所, 高性能陶瓷和超微结构国家重点实验室, 上海 200050)
}

\begin{abstract}
摘 要: 采用原位分析设备与传统方法相结合的方式研究了以 $\mathrm{Al}_{2} \mathrm{O}_{3}$ 和 $\mathrm{Y}_{2} \mathrm{O}_{3}$ 为烧结助剂的 $\mathrm{SiC}$ 陶瓷的液相烧结过程。 通过高温实时观测炉对样品在测试过程中的收缩曲线以及形貌变化进行了表征，以及对液相形成过程的模拟进行了 观测。采用传统分析方法研究了样品的相对密度、抗弯强度、物相组成以及微结构演变从 $1640^{\circ} \mathrm{C}$ 到 $1920^{\circ} \mathrm{C}$ 以 $40^{\circ} \mathrm{C}$ 为 间隔的变化情况。研究发现, 液相明显开始起作用的温度在 $1640^{\circ} \mathrm{C}$ 到 $1680^{\circ} \mathrm{C}$ 之间。经典的液相烧结三阶段理论可以 通过微结构以及相对密度等的分析来得到验证。该烧结体系的最佳烧结温度确认为 $1880^{\circ} \mathrm{C}$, 最高密度为 $(99.46 \pm$ $0.37) \%$, 最大强度为 $(650 \pm 26) \mathrm{MPa}$ 。
\end{abstract}

关 键 词: 碳化硅; 液相烧结; 原位研究; 微结构

中图分类号: TQ174

文献标识码: A 